\title{
UNDERWATER OBSERVATIONS ON THE FAUNA OF SHALLOW ROCKY AREAS IN THE NEIGHBOURHOOD OF PLYMOUTH
}

\author{
BY G. R. FORSTER \\ The Plymouth Laboratory
}

(Text-fig. I)

Since I954 I have made many underwater explorations in the neighbourhood of Plymouth using aqualung equipment. Diving has been generally restricted to rocky areas within the 15 -fathom line. In these areas, because of the difficulty of dredging, there has been little information available concerning the general pattern of the fauna; as Drach (1952) has pointed out, direct study with diving apparatus can not only give data on the depths at which various species flourish, but also the opportunity to collect the more secluded animals. It has not been possible to obtain such detailed results as Kitching, Macan \& Gilson (1934), or Knight-Jones \& W. C. Jones (1955), but these notes may provide an outline of the fauna as observed underwater in relation to the bottom topography.

To try to obtain as simple a picture of the fauna as possible, attention has been concentrated on places where the sessile animals are not intermixed with algae. In the shallowest water, therefore, the localities described are those with rock facies sufficiently shaded to exclude all but occasional algal plants.

Nearly all the best diving grounds are fully exposed to south-westerly winds; as these winds are generally prevalent it is frequently only possible to obtain sufficiently calm sea conditions once to twice a week even during the summer months. It is therefore very difficult to adhere to any fixed programme, and unless one is fortunate as I have been in having my own boat available at any time to take advantage of calm spells, opportunities for diving will be very restricted.

\section{THE WRECK, WHITSAND BAY}

The sunken hull of a 'Liberty' ship lies on the sand in $9 \mathrm{fm}$. ( $16 \mathrm{~m}$ ) about $\frac{3}{4}$ mile offshore, towards the eastern end of Whitsand Bay. The one remaining mast, which is always uncovered, forms a convenient mark and mooring post.

On the remains of the top deck and superstructure, which are about $\mathrm{I} 5 \mathrm{ft}$. $(4.5 \mathrm{~m})$ deep, there is some algal vegetation, including Alaria and rather scattered Laminaria hyperborea and Saccorhiza plants. Large numbers of small mussels (Mytilus sp.) occur around the top deck and, associated with them, numerous small Asterias rubens. Curiously enough, only small starfish 
were seen both in 1955 and I957, although the supply of mussels appeared amply sufficient to produce rapid growth. Possibly the Asterias population is considerably reduced by severe winter gales.

The two sides of the hull are both well colonized. On the west side in 1955 there were numerous Ophiothrix fragilis, various encrusting ascidians, especially Botrylloides leachi, sponges-particularly Suberites domuncula (=Ficulina ficus (L.)) - and an abundance of Metridium dianthus. The Metridium flourish especially on the underside of any horizontal surfaces, such as occur at the openings on to the 'tweendecks. This is the only inshore locality outside the Sound where many Metridium have been found, showing that it is lack of a suitable habitat rather than inability to withstand wave action which normally restricts them to pier piles and dock walls.

\section{QUEENER POINT}

Queener Point is situated $\frac{1}{2}$ mile north of Rame Head at the east end of Whitsand Bay. From the point an area of submerged rocks runs out for more than $\frac{1}{4}$ mile. Except for Peader Rock, which dries at L.w.o.s.T.L., the depth varies from 4 to $7 \mathrm{fm}$. ( $7-13 \mathrm{~m})$. Although the rock is the usual Dartmouth slate the strata run in the vertical plane and consequently the rock has been eroded in an unusual pattern-this area being notable for the large number of shallow gullies running roughly E.-W. in direction. These gullies are very roughly $6-8 \mathrm{ft}$. $\left(2-2 \frac{1}{2} \mathrm{~m}\right)$ deep and $8-\mathrm{I} 4 \mathrm{ft}$. $(2 \cdot 4-4 \cdot 2 \mathrm{~m})$ wide; their side walls provide a much more extensive area of vertical rock surface than is generally present on this part of the coast. In the narrower gullies the Laminaria vegetation is greatly reduced or absent, permitting the development of a moderately rich sessile fauna. It is not possible to do more than point out some of the commonest or most conspicuous species. Groups of the small orange ascidian Stolonica socialis are very common on the upper parts of the gully walls and in other situations where the Laminaria is not dense. Many of the small white anemone Actinothoë sphyrodeta also occur frequently in similar places. On the vertical rock walls there is a variety of sponges, ascidians and encrusting Bryozoa, together with scattered red algae especially Delesseria sanguinea which becomes covered, by the autumn, with a great abundance of the tiny white foraminiferan Haliphysema tumanowiczi. The case of this species is composed of sponge spicules. The encrusting sponges Amphilectus fucorum and Hemimycale columella are common, while tufts of the rare reddish horny sponge Ulosa tupha have been taken on one or two occasions. Colonies of Alcyonium digitatum are fairly common but not evenly distributed throughout the area, although no special habitat preferences were apparent. On the more sheltered or overhanging rock walls there are many cup corals, Caryophyllia smithi, some with the barnacle Pyrgoma anglicum growing on them. Also preferring sheltered conditions, colonies of Bugula turbinatum and other erect Bryozoa are fairly common. The finely branched 
black tentacles of Cucumaria normani are frequently seen protruding from holes in the gully walls; similarly, one may find the large tubicolous polychaete worm Bispira volutacornis made conspicuous by its double whorl of branchial filaments. Some specimens of the beautiful red serpulid Protula tubularia have been seen, but since the opening of its calcareous tube is invariably set well back in a rock crevice this species is extremely difficult to collect.

In early summer the ascidian Archidistoma aggregatum is quite common but disappears by the end of July.

\section{THE DRAYSTONE LEDGE}

One dive was made about 20 yd. west of the Draystone Ledge Buoy off Penlee Point, depth about $6 \mathrm{fm}$. (II m). The sea bed consists of low-lying reefs of slate not more than 2 or $3 \mathrm{ft}$. high and interspersed with patches of coarse gravel. Many Holothuria forskali were present, together with Stolonica socialis and red algae probably largely Heterosiphonia sp.

\section{INNER PENLEE POINT \\ (Admiralty Chart no. 30, as Inner Broady Cove)}

This is the only satisfactory position outside the breakwater where diving is possible with south-westerly winds. The rocks run out to depths of 4 or $5 \mathrm{fm}$. ( 7 or $9 \mathrm{~m}$ ), sometimes as reefs with sand between or as a gently shelving slope fringed by the sand. Generally the rocks are thickly covered with Laminaria even though the water is usually muddy and turbid since the main tidal flow in and out of the Sound runs close by. In the sand adjoining the rocks there are sometimes numerous Arenicola castings but they do not appear to extend beyond depths of 4-5 fm. No sublittoral records of Arenicola appear in the I957 Fauna List. It is, however, unlikely that the species generally penetrates more than a short distance below the lowest tidal level in the neighbourhood.

After the first few dives, this area was thought to have only a poor sessile fauna, limited to scattered pot-holes and overhanging ledges. The sponges Tethy a aurantium, Stelligera stuposa and Raspailia hispida were found in these places together with a variety of sessile animals though without any species being noticeably common.

In 1957, however, an interesting gully with an extensive overhanging rock wall was found off the south side of Inner Broady Cove. The approximate dimensions and depths in this gully are shown in the sketch chart (Fig. I). In a side branch from this gully large numbers of Phoronis hippocrepia live in a belt of dead Pomatoceros tubes about $\mathrm{I}-2 \mathrm{ft}$. above the sand. The end of the side branch terminates in an overhanging wall about $4 \mathrm{ft}$. high; this provides a sheltered rock surface colonized by many Caryophyllia smithi together with a few Balanophyllia regia, Gosse's golden cup coral. In the main gully the 
south wall, which varies in height from 6 to Io ft., and is undercut in many places, has the better developed sessile fauna. Where the overhang is considerable there is a rich growth of the brightly coloured 'anemone' Corynactis viridis. Stolonica socialis is again common on the upper parts of the wall near

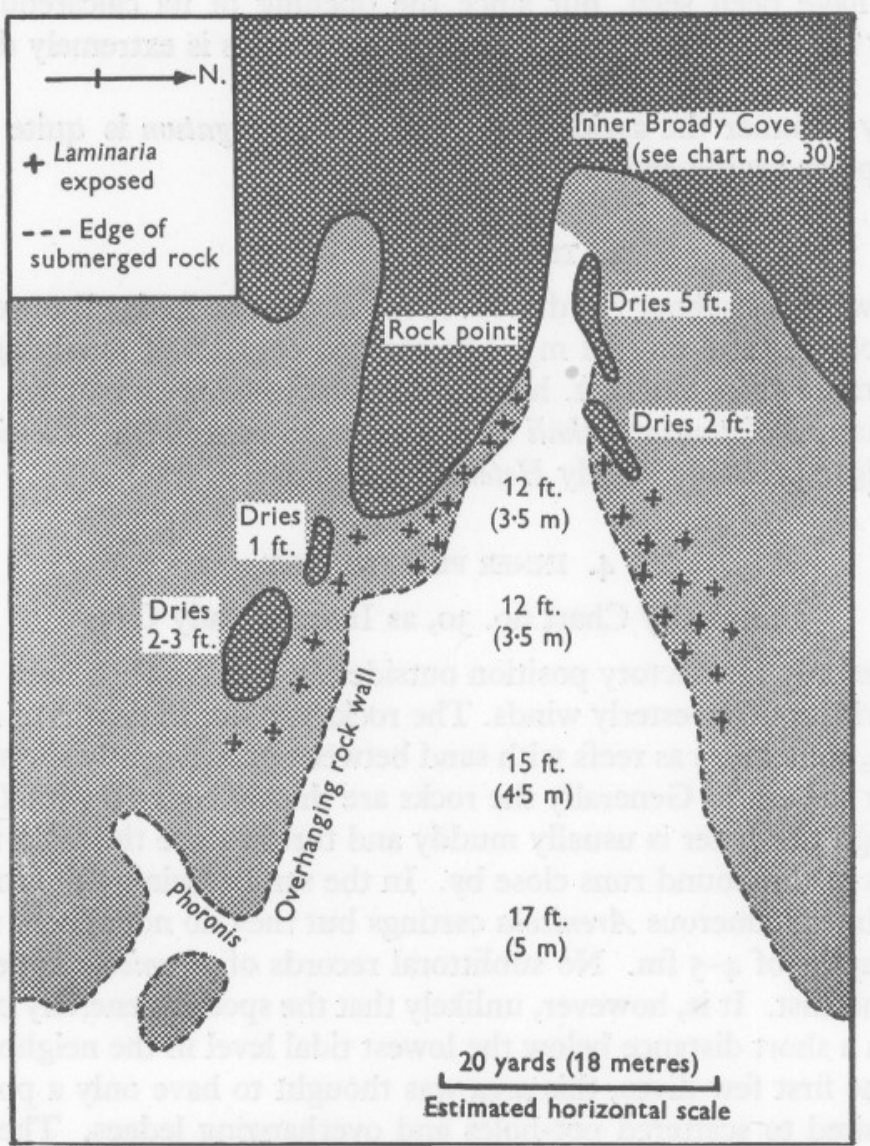

Fig. I. Sketch plan of gully about $\frac{1}{4}$ mile north of Penlee Point. Rocks exposed at low tide shown by dark tint, submerged rock by light tint: sandy bottom untinted.

the Laminaria fringe. Other parts of the vertical rock surface bear a variety of encrusting animals, the bulk of which are sponges and ascidians; these have not yet been sampled as it is hoped that an intensive survey will be made sometime in the future.

\section{THE TINKER SHOAL}

This is a large shoal area south of the main breakwater. The bottom is slate rock often in the form of low reefs with occasional stony or gravel patches. No steep-walled gullies have yet been found but there are some ledges with 
vertical rock walls of up to a height of six feet. A fine deposit of mud is generally present in the sheltered crevices of these ledges. The fauna is rather sparse, Stolonica socialis again being common together with the sponge Myxilla rosacea.

\section{THE SLIMERS}

A small isolated half tide reef at the west end of Wembury Bay, the Inner Slimers, lies about $\frac{1}{4}$ mile east of the Mewstone. On the north or landward side of the reef there is a projecting rise of rock just below L.W.O.S.T.L. which protects and shades the rock surface below it. The erect forms of Bryozoa (Crisia spp., and Scrupocellaria reptans) are particularly common in this sheltered niche. There are also various sponges forming a thin loose mat held between the stalks of the Bryozoan colonies; Suberites epiphytum, Myxilla rosacea and Dysidea fragilis are all common together with the firmer white crust of Leuconia nivea. From a rock sample of $50 \mathrm{I} \mathrm{cm}^{2}$, I3I small amphipods (chiefly Parajassa) were counted.

\section{KITCHING'S GULLY, WEMBURY BAY}

This gully lies 60 yd. east of the Tomb Rock shown on Admiralty Chart no.95. The sublittoral fauna was surveyed in 1931 and 1932 by Kitching et al. (1934). It has been interesting to look for changes in the fauna which have taken place in the 25 years since this survey was made. The sponge Halichondria panicea is no longer common and there is no sign of a Distomus-Halichondria association. The only Halichondria found during 1956 and 1957 were a few patches at the shallow end of the gully remote from the area of the survey. The Distomus variolosus is still abundant, forming bright reddish patches through which the large siphons of Polycarpa pomaria may frequently be seen projecting. The large majority of the Distomus grow on the tough leathery tests of the Polycarpa which curiously enough was not taken by Kitching. Corynactis is rather more common now than would appear from their survey, particularly on the shaded area such as Kitching's position M p. 683, previously dominated by sponges. The south patch of Stolonica socialis still exists at the seaward end of the gully.

On the west side of the small rocky point, which forms the west side of Kitching's gully, there is a wide undercut ledge. On the underside of this ledge numerous small orange Sagartia sp. (probably Sagartia elegans) have been abundant during the last two summers. Distomus is still common but not so widespread as in the gully.

On the east side of the gully a small area of submerged rocks provides rather similar conditions; there are still small patches of Distomus, but in all shaded areas Corynactis is more abundant. Two hydroids, Plumularia setacea and Sertularia operculata are also very common in places. 


\section{THE STOKE POINT AREA}

The fauna of a rock gully near Stoke Point Rock has already been described (Forster, 1954). On the latest copies of Admiralty Chart no. I267 Stoke Point Rock has been renamed Hilsea Point Rock following the Ordnance Survey, but as Stoke Point is the name in general use it seems better to retain it for the present.

On the part of the shore lying about north-east from Stoke Point Rock several long narrow reefs run out in a south-westerly direction. Most of the gullies between these reefs have a purely algal covering, however one rather narrower gully was found with side walls at least $15 \mathrm{ft}$. high and an abundant sessile fauna. The position of this gully is $037^{\circ} \mathrm{T}$ from Stoke Point Rock, distance $3 \frac{1}{2}$ cables. The depth at the bottom is about $4 \mathrm{fm}$. $(7 \mathrm{~m})$. The west side wall has a slight overhang; on it occur several species usually only found in much deeper water; there was one colony of the gorgonian Eunicella verrucosa and several of the ascidians Phallusia mammillata and Diazona violacea. There are numerous Caryophyllia, the feathery bryozoan Crisia spp. in abundance, together with the following sponges: Dercitus bucklandi in crevices, Hemimycale columella, Pachymatisma johnstonia, Mycale macilenta, Leucosolenia coriacea and one small patch of orange incrustation identified as Antho involvens.

About 600 yd. farther east along the coast, the three large Netton Rocks and submerged reef form a slight breakwater which makes it possible to anchor a boat close inshore. There are a number of gullies in this area (named 'Bloody Cove' on the $2 \frac{1}{2}$ in. Ordnance Survey maps) roughly similar in proportion to those of Queener Point and Inner Broady Cove but with scarcely any sessile fauna. Instead the vertical rock walls are covered with algae in spite of the shading caused by overhanging Laminaria plants. The algae are often species more generally found in deeper water, e.g. Dictyopteris membranacea and Halopteris filicina. This increase in algal coverage is doubtless due to the lack of suspended material in the water, which is always much clearer than it is nearer the Sound. Secchi disk readings were twice taken at Inner Broady Cove and then as quickly as possible off Netton Rocks, the results were:

$$
\begin{array}{lr}
\text { Inner Broady Cove } & 6-6 \frac{1}{4} \mathrm{~m} \\
\text { Netton Rocks } & \text { I I-I2 m }
\end{array}
$$

A few narrow gullies not more than $3 \mathrm{ft}$ wide did contain some sessile animals, encrusting Bryozoa and ascidians, but the algal coverage was still estimated to be over $50 \%$. 


\section{SALCOMBE}

Several deep clefts have been found in the submerged reef which runs for a short distance eastwards from the Great Mewstone off Bolt Head. These clefts have vertical walls over $20 \mathrm{ft}$. in depth with a rich sessile fauna. Although only one short dive has been made in this position, the ascidian Distomus was found to be clearly abundant. This is of interest as being the only position other than Kitching's gully in Wembury Bay where this ascidian is really abundant. Corynactis and Crisia spp. are also fairly common.

\section{IO. THE EDDYSTONE ROCKS}

The Admiralty Chart no. 1267 shows a large-scale plan of the Eddystone rocks, which lie about 9 miles offshore. Several rocks are uncovered at low tide, the Southern Reef in particular forming a small natural breakwater on which landing is occasionally possible in extremely calm conditions. The area of reef within the $\mathrm{Io} \mathrm{fm}$. line is a little over $\frac{1}{10}$ sq.mile. The water is generally much clearer than at any of the inshore positions except Bloody Cove. The rock is a very hard gneiss.

Several dives have been made on a line running about south-west from the mid-point of the south reef. From L.w.o.s.T.L. there is a narrow fringe of the brown alga Alaria, which is quickly replaced by large Laminaria hyperborea plants. Many brown tubes of the amphipod Parajassa pelagica are common in the space between the Laminaria holdfasts to a depth of about $7 \mathrm{fm}$. (13 m), penetrating much farther than under inshore conditions; their limit at Wembury being only I-2 fm. (2-4 m). The lower limit of the Laminaria has not yet been ascertained, below I $2 \mathrm{fm}$. (22 m), however, it becomes sparse. The reef slopes fairly steeply down to IO-I2 $\mathrm{fm}$. (I8-22 m), although most of the surface is algal covered there are some ridges, clefts, and occasional very large boulders, with vertical or overhanging sides. Wherever the rock is sufficiently shaded Corynactis is particularly common, the different colour varieties forming red, green or brown patches. The light green variety appeared bright yellow at $4 \mathrm{fm}$. ( $7 \mathrm{~m})$. In well-sheltered crevices from $7-8 \mathrm{fm}$. ( $13-15 \mathrm{~m})$ downwards, besides Corynactis, towards the outside there is generally a rich growth of Crisia spp. giving the effect of a white moss. At slightly greater depths-around II fm. (20 m) the Crisia becomes more extensive. From $13 \mathrm{fm}$. (24 m) downwards the slope becomes gradual and these rocks are interspersed with patches of coarse shell gravel.

At all depths it is difficult to collect small stones or boulders as they are invariably very tightly packed. The few stones which have been examined have many Caryophyllia smithi, together with thin yellow encrusting sponges; notably Spanioplon armaturum, Myxilla rosacea and Hymedesmia spp.

On the east side of the Southern Reef it is possible to anchor within a few yards of the rock if there is a westerly wind and easterly going tide. There are 
several rocks which appear dangerous in the clear water, but actually have 2-3 fm. (4-6 m) of water over them at L.w.o.s.T. These rocks form one side of a gully with a maximum depth of $9 \mathrm{fm}$. ( $16 \mathrm{~m}$ ). Even the nearly vertical sides of the gully bear some Laminaria plants, but in a few overhanging places there are again fine Corynactis growths, and also numerous Actinothoë sphyrodeta; this species reaches a much greater individual size (disk diameter of nearly $I$ in.) than it does inshore.

On the floor of the gully Laminaria plants are rather infrequent, being largely replaced by Dictyota dichotoma and Heterosiphonia. Several fine pinkish colonies of the ascidian Clavelina sp. have been observed, together with purple clumps of the sponge Adocia cinerea and the ubiquitous Hemimycale columella.

\section{I50 yards north of lighthouse}

The depth at this position is a little over $10 \mathrm{fm}$. (I8 m), and the bottom consists of large boulders and stones overgrown by tall Laminaria plants with here and there even larger plants of Saccorhiza bulbosa. The Laminaria stipes are well colonized by various red algae and various animals, chiefly hydroids and Bryozoa; Sertularia operculata is particularly common. Echinus esculentus is also abundant and has an estimated density of one sea urchin to about $5^{-10} \mathrm{~m}^{2}$. In this area the Echinus are frequently observed climbing up the Laminaria stipes.

60 yards north-west from old lighthouse stump

The reef slopes rather steeply down from 5 to $\mathrm{I} 2 \mathrm{fm}$. (9-22 m). There are again fine growths of Corynactis on several overhanging rock faces. Two specimens of Lima hians, a tunnel-building lamellibranch, were taken from underneath small boulders in this area.

\section{THE HAND DEEPS}

A misnamed submerged reef, the Hand Deeps, with a minimum depth of $4 \mathrm{fm}$. ( $7 \mathrm{~m}$ ) lies $3 \frac{1}{2}$ miles north-west from the Eddystone. The reef is composed of a micaceous schist evidently not so resistant to the waves as the Eddystone rock. In one position on the south side of the reef at $13 \mathrm{fm}$. ( $24 \mathrm{~m}$ ) the rock slopes gently downwards and the bottom is largely strewn with boulders, the largest being 4 or $5 \mathrm{ft}$. in height. Laminaria was still present at this depth. Two dives have been made on the north side of the reef.

In the first dive a steeply sloping rock bottom was found with a gradient of about $\mathrm{I}$ in 2 from $9 \mathrm{fm}$. ( $16 \mathrm{~m}$ ) downwards. There were no Laminaria plants after $12 \mathrm{fm}$. (22 $\mathrm{m}$ ) and no other algae except Lithothamnion after $\mathrm{I} 4 \mathrm{fm}$. $(27 \mathrm{~m})$. From $\mathrm{I} 2$ to $\mathrm{I} 7 \mathrm{fm}$. (22-3I m) Corynactis was again abundant on vertical surfaces, while Caryophyllia and Alcyonium digitatum were common. There were also scattered hydroid colonies Nemertesia sp. in evidence. The second dive was made in a position probably near the north-east corner of 
the reef. At $12 \frac{1}{2} \mathrm{fm}$. $(23 \mathrm{~m})$ there were scattered Laminaria plants growing on a gentle rock slope, these were replaced completely at $15 \mathrm{fm}$. $(27 \mathrm{~m})$ by Dictyopteris and various red algae. Numerous Echinus esculentus were also present.

\section{THE EAST RUTTS AREA}

One dive has been made on a rock pinnacle, depth $7 \mathrm{fm}$. (I3 $\mathrm{m}$ ), lying about 5 miles offshore in Bigbury Bay. This pinnacle is situated I mile to the east of the East Rutts. The fauna and flora at $8-9 \mathrm{fm}$. (I4-I6 m) depth are generally similar to those of Stoke Point Rock. There are large yellow clumps of the sponge Cliona celata, colonies of Alcyonium digitatum and numerous Echinus and Holothuria. In a small pit two fine colonies of the ascidian Diazona violacea were observed. This area is noteworthy for the presence of many clumps of the sponge Halichondria panicea in the unusual form shown in Bowerbank, Vol. 3, plate xl, figs. 2 and 5. Elsewhere in the Plymouth area Halichondria has not been found below about $2 \mathrm{fm}$. $(4 \mathrm{~m})$. Whether its abundance here can be related to the different rock substratum is not certain, but there can be little difference in the physical conditions compared with Stoke Point other than the nature of the rock.

\section{DISCUSSION}

In general the sessile fauna of submerged rocks off Plymouth tends to be rich in sponges, polyzoans and ascidians: compared with the low-tide area it is rather poor in actinians, and there are few gastropods apart from nudibranchs. The only common cirripede, Verruca stroemia, is mostly restricted to the underside of stones. Apart from Corynactis on the outlying reefs, no single species has been observed which could be regarded as dominant over an appreciable area. This situation contrasts with Bardsey Island, where KnightJones \& W. C. Jones (1955) found various species of Polyzoa to be dominant, and differs also from Barn Pool in Plymouth Sound where the ascidian Dendrodoa grossularia covers all the stones at depths of 2-4 fm. (4-7 m) and forms a belt just below the Laminaria.

On the outlying reefs it would be reasonable to regard Corynactis as a dominant species on overhanging or shaded rock surfaces; but closer inshore, though still very common, it is generally mixed with other species, and for no obvious reason is virtually absent from the Queener Point area.

The general impression of the sessile fauna, particularly below $5 \mathrm{fm}$. (9 m), as it might be observed on a gully wall 3 or $4 \mathrm{~m}$ high is of a random dispersal of most species, with encrusting forms rarely managing to cover an area of $\frac{1}{20} \mathrm{~m}^{2}$. A possible explanation of this effect is the browsing habit of the Echinus esculentus. A few Echinus will keep walls of an aquarium tank, 2-3 $\mathrm{m}^{2}$ in area, almost completely free from sessile animals; since in most localities they are common below $8 \mathrm{fm}$. ( $15 \mathrm{~m}$ ) the Echinus can be assumed to be 
continually sweeping clear small areas of rock throughout the course of the summer and to some extent throughout the year. The places available for larval settlement at any one time would therefore be widely scattered. Predation of the youngest stages may be expected from decapod crustacea and asteroids; which would again tend to prevent the growth of any large group of a single species.

As Lilly, Sloane, Bassindale, Ebling \& Kitching (1953) observe, many observations and experiments on small areas will be necessary before the effects of predation can be assessed.

Part of the diving gear was made available by a grant from the Royal Society. I am grateful to many people who have acted as diver's attendant and always managed to recover me safely.

\section{SUMMARY}

A brief description is given of the commonest sessile animals observed by diving from twelve positions near Plymouth, including three offshore reefs. The coelenterate Corynactis viridis is generally abundant on shaded rock surfaces. Many sessile species, even where common, tend to be dispersed in scattered patches or colonies; from this it is suggested that their distribution is affected by predation from browsing animals, particularly Echinus esculentus.

\section{REFERENCES}

DrACH, P., I952. Lacunes dans la connaissance du peuplement des mers et utilisation des scaphandres autonomes. La Revue Sci., Paris, No. 3315, pp. 58-72.

Forster, G. R., I954. Preliminary note on a survey of Stoke Point Rocks with selfcontained diving apparatus. F. mar. biol. Ass. U.K., Vol. 33, pp. 34I-44.

Kitching, J. A., MACAN, T. T. \& GILson, H. C., I934. Studies in sublittoral ecology. I. A submarine gully in Wembury Bay, South Devon. F. mar. biol. Ass. U.K., Vol. 19, pp. 677-705.

KNIGHT-JoNES, E. W. \& JoNES, W. CLIFFord, 1955. The fauna of rocks at various depths off Bardsey. I. Sponges, Coelenterates and Bryozoans. Bardsey Observatory Report, 1955, pp. I-8.

Lilly, S. J., Sloane, J. F., Bassindale, R., Ebling, F. J. \& Kitching, J. A., 1953. The ecology of the Lough Ine rapids with special reference to water currents. IV. The sedentary fauna of sublittoral boulders. F. anim. Ecol., Vol. 22, pp. 87-I22.

\section{APPENDIX}

The numbers of dives made at the localities which have been described are tabulated. The period is from I954 to 1957 . The numbers include dives made specifically for collecting purposes when faunistic observation is very limited. The time spent underwater has not always been recorded, but shallow dives generally last at least $30 \mathrm{~min}$, and for deeper areas the average would be about $20 \mathrm{~min}$.

$\begin{array}{llllllllllllll}\text { Area } & \cdots & \text { I } & 2 & 3 & 4 & 5 & 6 & 7 & 8 & 9 & \text { IO } & \text { II } & \text { I2 } \\ \text { No. of dives } & \cdots & 3 & \text { I } 8 & \text { I } & \text { II } & 3 & 3 & 6 & 6 & \text { I } & 9 & 3 & \text { I }\end{array}$

